\title{
Antiparasit Ekstrak Gliricidia sepium Secara In Vivo Terhadap Sarcoptes scabiei Kelinci di Pesanggaran, Banyuwangi
}

\author{
Antiparasitic of Gliricidia sepium In Vivo on Rabbits Infected Sarcoptes scabiei in \\ Pesanggaran, Banyuwangi
}

\author{
Silvia Martha Kristina ${ }^{1 *}$, Agus Sunarso², Aditya Yudhana ${ }^{2}$ \\ ${ }^{1}$ Mahasiswa Pendidikan Dokter Hewan, ${ }^{2}$ Departemen Parasitologi Veteriner, Fakultas Kedokteran Hewan, \\ Universitas Airlangga, Kampus C Mulyorejo, Surabaya, Jawa Timur, Indoneisa, 60115, Telp (031)5993051 \\ *Corresponding author: krackerbanyuwangi23@yahoo.com
}

\begin{abstract}
Abstrak
Penelitian bertujuan untuk mengetahui ekstrak daun gamal (Gliricidia sepium) secara in vivo terhadap Sarcoptes scabiei kelinci. G. sepium dikoleksi di wilayah sekitar Desa Pesanggaran, Banyuwangi. Jenis penelitian adalah eksperimental, subjek penelitian adalah kelinci yang terinfeksi S. scabiei sejumlah 20 ekor, dengan 5 perlakuan 4 kali pengulangan. Pembagian kelompok terdiri atas $(\mathrm{K}+)$ kelompok kontrol positif dengan invermectin, (K-) kontrol negatif, kelompok perlakuan berisi konsentrasi ekstrak daun gamal pada perlakuan satu (P1) sebesar 10\%, perlakuan dua (P2) sebesar 20\%, perlakuan tiga P3 (30\%). Hasil penelitian ini menunjukkan (P2) ekstrak daun gamal $20 \%$ berpengaruh pada kesembuhan luka pada kelompok perlakuan dengan pertumbuhan rambut, keropeng dan penebalan kulit.
\end{abstract}

Kata kunci: Sarcoptes scabiei, daun gamal, Gliricidia sepium

\section{Abstract}

This study aimed to determine gamal leaf extract (Gliricidae sepium) in vivo against Sarcoptes scabiei in rabbits. Gamal leaves were collected in Pesanggaran, Banyuwangi. The type of study was experimental, the subjects of the study were 20 rabbits infected with S. scabiei, with 5 treatments 4 replications. Group distribution consisted of $(K+)$ positive control group with invermectin, $(K-)$ negative control, treatment group containing the concentration of gamal leaf extract at treatment one (P1) by 10\%, treatment two (P2) by 20\%, treatment three (P3) 30\%. The results of this study showed that the gamal leaf extract had an effect on wound healing in the treatment group with hair growth, scab and skin thickening with a concentration of 20\% (P2).

Keywords: Sarcoptes scabiei, gamal leaves, Gliricidia sepium

Received: 12 Agustus 2019

Revised: 11 November 2019

Accepted: 28 November 2019

\section{PENDAHULUAN}

Kelinci merupakan hewan yang memiliki potensi besar sebagai hewan ternak. Kelinci digunakan untuk bisnis sampingan olahan makanan. Penyakit dapat mengakibatkan kerugian ekonomi karena menurunnya produktivitas bahkan kematian, namun dampak negatif yang lain yaitu menurunkan minat peternak untuk mengembangkan usahanya (Ermawati dkk., 2014; Arifin dkk., 2019).

Penyakit parasitik merupakan salah satu faktor yang dapat menurunkan produktivitas ternak. Parasit bertahan dalam tubuh host dengan memakan jaringan tubuh, mengambil nutrisi yang dibutuhkan dan menghisap darah hospes. Penyakit scabies menyebabkan terjadinya penurunan bobot badan, pertumbuhan yang lambat, penurunan daya tahan tubuh dan kematian hospes. Ternak yang terinfeksi parasit menjadi rendah nilai jualnya karena mengalami kekurusan. Penyakit parasitik yang biasa pada ternak yaitu scabies (Khan dkk., 2008). Scabies atau yang lebih dikenal dengan nama kudis adalah penyakit yang disebabkan oleh Sarcoptes scabiei yang hidup di dalam kulit hewan dengan cara menggali membentuk terowongan untuk bereproduksi, ditandai dengan perkembangan 
keropeng, gatal yang parah dan kehilangan rambut (Jarmuda et al., 2012).

Program pengendalian scabiosis yang disebabkan S. scabiei var. cuniculi sampai sekarang masih sulit, karena banyak faktor yang mempengaruhi termasuk faktor geografis dengan wilayah yang beriklim tropis menyebabkan penyakit kulit menjadi endemis. Kasus scabies pada kelinci antara lain: scabies pada ternak kelinci di Desa Sajen, Kecamatan Pacet, Kabupaten Mojokerto adalah sebesar $17.27 \%$, dengan tingkat keparahan ringan $26.32 \%$ dan tingkat keparahan sedang $73.68 \%$ (Laksono dkk., 2018; Suroiyah dkk., 2018).

Pengobatan scabies pada kelinci biasanya menggunakan ivermectin diberikan dengan dosis $0.2 \mathrm{mg} / \mathrm{kg}$, doramectin pada $200 \mu \mathrm{g} / \mathrm{kg}$ dengan jarak pengulangan satu minggu berikutnya. Ivermectin merupakan obat berspektrum luas non higroskopik, semi sintetik, antehelminthik, antiparasit yang terbukti efektif melawan endoparasit dan ektoparasit (Marimuthu et al., 2015). Ivermectin terbukti kurang efektif karena lesi terus berkembang, hal ini mungkin karena rendahnya tingkat sistemik obat atau karena reinfestasi kambing oleh tungau dari lingkungan. Tungau dapat hidup dilingkungan seperti lantai hingga 12 minggu (Demite et al., 2015).

Kambing yang terserang scabies sering dibiarkan begitu saja karena terkendala dengan harga obat scabies yang paten mahal. Penyakit ini sangat cepat dari ternak satu ke ternak lainnya dalam satu kandang dan jika tidak diatasi dapat menyebabkan kematian hingga $67 \%$, obat scabies mahal maka cara yang mudah menggunakan tanaman herbal yang mudah didapat dan mudah diaplikasikan. Tanaman yang mempunyai potensi sebagai obat scabies adalah Gamal yang dalam bahasa latin dinamakan Gliricidia sepium. G. sepium merupakan tanaman pelindung yang daunnya biasa diberikan sebagai hijauan pakan ternak ruminansia karena memiliki nilai nutrisi yang tinggi (kandungan protein 18-30\%) dan kecernaan tinggi (70\%). Di samping itu, $G$. sepium telah dimanfaatkan petani secara luas sebagai insektisida nabati karena mengandung tanin, zat racun dikumerol dan $\mathrm{HCN}$ yang toksik terhadap serangga. G. sepium mempunyai kandungan bahan aktif alkaloid, steroid, terpenoid, tanin, polifenol, saponin dan kumarin, kumarin bersifat insektisida, rodentisida dan bakterisida (Badan Litbang, 2011). Penelitian ini bertujuan untuk menguji efektivitas ekstrak $G$. Sepium secara in vivo pada kelinci dengan $S$. scabiei.

\section{METODE PENELITIAN}

Penelitian telah mendapat persetujuan etik hewan coba dari Fakultas Kedokteran Hewan Universitas Airlangga untuk menghindari penyalahgunaan hewan dan tindakan yang memungkinkan stress pada hewan.

Sampel penelitian yang digunakan berupa kelinci 20 ekor yang menunjukkan gejala klinis terinfeksi scabies dan hasil kerokan kulit. Besar sample dihitung dari kelinci yang menunjukkan gejala klinis dan positif terinfeksi S. scabiei dengan pemeriksaan laboratorium.

Penelitian terbagi menjadi $(\mathrm{K}+)$ kelompok dengan invermectin, (K-) kontrol negatif, kelompok perlakuan (P1, P2, P3) berisi konsentrasi ekstrak sebesar 10\%, 20\%, 30\%. Alat yang digunakan pada penelitian ini antara lain: neraca analitik, mesin giling, toples, kertas saring, spatula, gelas ukur $500 \mathrm{ml}$, Rotary Evaporator Buchi, vacum Evaporator, wadah salep, scalpel dan blade, tabung vial, pipet tetes, objek glass, cover glass, mikroskop. Bahan pada penelitian yang digunakan antara lain: $G$. sepium, minyak kelapa, methanol, aquades, ivermectin, dan $\mathrm{KOH} 10 \%$.

Pengamatan dan pencatatan pada luka dilakukan setiap hari selama 7 hari dengan mengamati pertumbuhan rambut, keropeng dan penebalan kulit terhadap luka scabies pada kelinci yang terinfeksi. Kriteria penilaian menurut Laksono, (2018) pengamatan luka dilihat dari pertumbuhan rambut terdapat 0-2 skor, untuk skor 0 tidak ada rambut yang tumbuh pada permukaan luka, skor 1 rambut yang tidak tumbuh $(<1 \mathrm{~cm})$, skor 2 rambut yang tidak tumbuh $(0-1 \mathrm{~cm})$. Pengamatan luka dilihat dari adanya keropeng pada luka terdapat 0-2 skor, untuk skor 0 keropeng ditemukan pada seluruh 
permukaan luka, skor 1 terdapat keropeng dengan luas $(<1 \mathrm{~cm})$ pada permukaan luka, skor 2 terdapat keropeng dengan luas $(0-1 \mathrm{~cm})$ pada permukaan luka. Pengamatan luka dilihat dari penebalan kulit terdapat 0-2 skor, skor 0 terdapat penebalan kulit yang ditemukan diseluruh permukaan luka, skor 1 penebalan kulit $(<1 \mathrm{~cm})$ pada permukaan luka, skor 2 penebalan kulit (0$1 \mathrm{~cm})$ pada permukaan luka.

Data penelitian dinilai dengan skoring pengamatan luka yang selanjutnya akan diuji menggunakan uji Kruskal-Wallis dan dilanjutkan dengan uji Mann-Whitney. Data yang diperoleh akan diolah dengan program SPSS.

\section{HASIL DAN PEMBAHASAN}

Hasil dari 20 ekor kelinci yang diperiksa secara klinis dan hasilnya positif scabies. Pemeriksaan mikroskopis hasil kerokan kulit pada kelinci didapat positif scabies yang tumbuh dan berkembang biak di permukaan kulit pada telinga kelinci (Gambar 1).

Morfologi dari S. scabiei yaitu bentuknya oval, punggung yang cembung dan perutnya rata. Kaki yang bersegmen, pada betina terdapat bulu cambuk pada pasangan kaki ke-3 dan ke-4, jantan terdapat bulu hanya pada pasangan kaki ke-3, dan 4 pasang kaki pada S. scabiei dewasa (Arlian, 2017).

Hasil penilaian tingkat kesembuhan pada kelinci yang terinfeksi scabies berdasarkan pertumbuhan rambut, pengurangan keropeng, penebalan kulit dengan kriteria penilaian berdasarkan tingkat keparahan luka, pada 20 sampel kelinci didapatkan hasil penilaian seperti pada Tabel 1.

Kelinci dengan gejala klinis berupa keropeng dan alopecia pada bagian wajah meliputi area hidung, mulut, mata, kuping dan bagian kaki. Pengamatan pertumbuhan rambut, keropeng dan ketebalan kulit dilakukan setelah 7 hari pengobatan, tingkat kesembuhan pada setiap kelompok perlakuan semakin meningkat seiring tingkat konsentrasi $G$. sepium. Tingkat kesembuhan tertinggi terdapat pada kontrol positif menunjukkan hasil yang baik pada pertumbuhan rambut, keropeng dan ketebalan kulit terdapat kesembuhan yang signifikan.

Kontrol negatif menunjukkan tidak ada perubahan pada pertumbuhan rambut, keropeng dan ketebalan kulit. Ekstrak $G$. sepium konsentrasi $10 \%$ tidak ada perubahan terhadap pertumbuhan rambut, keropeng dan ketebalan kulit. Ekstrak G. sepium 20\% terdapat perubahan tetapi tidak signifikan terhadap pertumbuhan rambut, keropeng dan ketebalan kulit. Ekstrak $G$. sepium $30 \%$ terdapat perubahan yang signifikan pada pertumbuhan rambut, keropeng dan ketebalan kulit karena memiliki senyawa aktif dari G. sepium yang lebih banyak.

Terdapat perbedaan yang signikan antara kontrol positif, kontrol negatif ekstrak G. sepium konsentrasi 10\%, 20, dan 30\% terhadap pertumbuhan rambut, pengurangan keropeng dan ketebalan kulit kesembuhan pada hari ke-1 sampai hari ke-7. Hal ini menunjukkan bahwa aktivitas ekstrak G. sepium konsentrasi $30 \%$ menunjukkan aktivitas baik dan efektif digunakan untuk terapi penyembuhan scabies pada kelinci.

Komponen bahan aktif kumarin yang terdapat didalam ekstrak G. sepium efektif mencegah pertumbuhan dan perkembangan parasit dengan cara menghambat metabolisme dan melisiskan dinding sel parasit, kematian parasit dapat diamati dengan makroskopis dilihat dari tingkat kesembuhan dan mikroskopis diliat dari berkurangnya S. scabiei (Becker, 2010). Ekstrak G. sepium dengan vehiculum cocoa oil berfungsi memudahkan dan mengoptimalkan mekanisme kerja obat mencapai sasaran predileksi parasit di bawah permukaan kulit (Joenoes, 2010).

Senyawa toksik didapat dari proses ekstrak metanol $G$. sepium seperti flavonoid dan kumarin (Astiti dkk., 2016). Mekanisme senyawa flavonoid menurut Purwaningsih dkk. (2015) yaitu dapat mengiritasi kulit serangga dan bersifat insektisida dengan membunuh serangga melalui racun perut dan racun syaraf . Racun masuk melalui makanan yang diabsorbsi oleh dinding pencernaan serangga. Senyawa toksik $G$. sepium sebagai racun perut di absorbsi pada 
Tabel 1. Hasil penilaian tingkat kesembuhan luka scabies

\begin{tabular}{cccc}
\hline Perlakuan & Pertumbuhan Rambut & Penurunan Keropeng & Penebalan Kulit \\
\hline K+ & $2.00 \pm 0.00^{\mathrm{b}}$ & $1.75 \pm 0.50^{\mathrm{b}}$ & $1.00 \pm 0.00^{\mathrm{b}}$ \\
K- & $0.00 \pm 0.00^{\mathrm{a}}$ & $0.00 \pm 0.00^{\mathrm{a}}$ & $0.00 \pm 0.00^{\mathrm{a}}$ \\
P1 & $0.00 \pm 0.00^{\mathrm{a}}$ & $0.25 \pm 0.50^{\mathrm{a}}$ & $0.75 \pm 0.50^{\mathrm{b}}$ \\
P2 & $1.50 \pm 0.58^{\mathrm{b}}$ & $1.50 \pm 0.58^{\mathrm{b}}$ & $1.25 \pm 0.50^{\mathrm{b}}$ \\
P3 & $1.75 \pm 0.50^{\mathrm{b}}$ & $1.75 \pm 0.50^{\mathrm{b}}$ & $1.25 \pm 0.50^{\mathrm{b}}$
\end{tabular}

Superskrip berbeda pada kolom yang sama menunjukkan berbeda signifikan $(\mathrm{p}<0.05)$

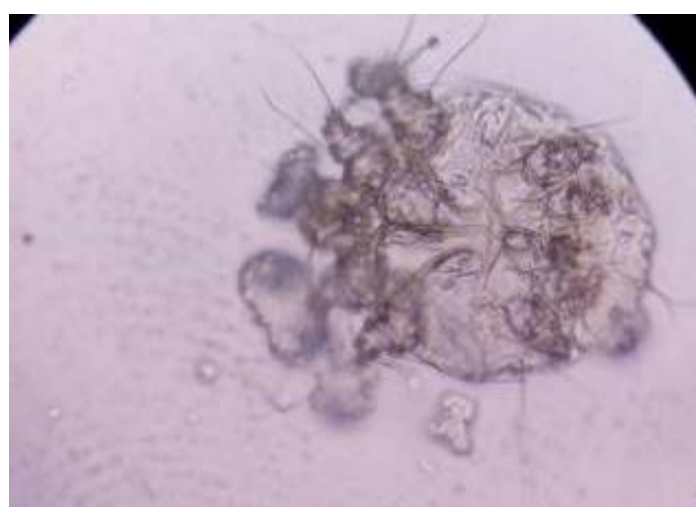

Gambar 1. S. scabiei pada pemeriksaan laboratorium

dinding saluran cerna bagian tengah, bagian ini tidak dilapisi oleh kutikula dan fungsinya untuk saluran cerna yang utama menyerap nutrisi dan sekresi enzim pencernaan. Dinding pencernaan bagian depan dan akhir dilapisi dengan kutikula (Ahdiyah dkk., 2005). Flavonoid berpengaruh sebagai racun (stomach poisioning) yang terlarut dalam air maupun pelarut organik menghasilkan senyawa yang lebih polar. Diabsorbsi pada dinding saluran cerna bagian bawah yang menyebabkan permeabilitas dinding tracktus digestivus munurun (Wati, 2010).

Menurut Annafi, (2016) insektisida dapat menghambat asetilkolinesterase. Absorbsi flavonoid disirkulasikan dalam hemolimfe sampai ke saraf dan bekerja meracuni sel syaraf, menghambat enzim asetilkolinesterase sebagai enzim hidrolisis transmiter kolinergik Asetilkolin (ACTH). ACTH sebagai neurotransmitter terakumulasi pada sitoplasma ujung saraf sinap (Neuromuscular juction) dalam kadar tinggi hingga menyebabkan aktivitas kolinergik berlebih menimbulkan kekejangan otot, terjadi paralysis, kelemahan syaraf sehingga terjadi gangguan terhadap inervasi beberapa organ menjadi gagal organ dan berakhir kematian pada serangga (Annafi, 2016).

\section{KESIMPULAN}

Ekstrak G. sepium berpotensi sebagai antiparasit S. scabiei dengan konsentrasi ekstrak G. sepium $20 \%$. Variabel yang dapat diamati pasca pemberian ekstrak adalah pertumbuhan rambut, penurunan keropeng dan penebalan kulit terhadap luka scabies pada kelinci.

\section{UCAPAN TERIMA KASIH}

Penulis ingin menyampaikan terima kasih kepada Dekan Fakultas Kedokteran Hewan Universitas Airlangga Prof. Dr. Pudji Srianto, drh., M.Kes. atas kesempatan mengikuti pendidikan dan penelitian di Fakultas Kedokteran Hewan Universitas Airlangga.

\section{DAFTAR PUSTAKA}

Ahdiyah, I., Purwani, K.I. 2015. Pengaruh ekstrak daun mangkokan (Nothopanax scutellarium) sebagai larvasida nyamuk Culex sp. Jurnal Sains dan Seni ITS, 4(2), 32-36. 
Annafi, F.N. 2016. Efikasi Air Perasan Rimpang Lengkuas Putih (Alpinia Galanga L. Willd) Sebagai Larvasida Nabati Nyamuk Aedes Aegypti. [Doctoral dissertation] Universitas Negeri Semarang.

Arifin, K., Kusnoto, A.Y., Sunarso, A., Purnama, M.T.E., Praja, R.N. 2019. Prevalensi Haemonchiasis Pada Kambing Peranakan Etawah di Kecamatan Kalipuro, Banyuwangi. Jurnal Medik Veteriner, 2(2), 108-111.

Arlian, L.G., Vyszenski-Moher, D.L. 1996 Responses of Sarcoptes scabiei (Acari: Sarcoptidae) to nitrogenous waste and phenolic compounds. J. Med. Entomol., 33(2), 236-43.

Astiti, L.G.S., Prisdiminggo, Panjaitan, T. 2016. Efektivitas Ekstrak Daun Gamal (Glyricidia sepium) terhadap larva cacing Trichostrongylus sp. Pada Kambing PE. Banjarbaru. Prosiding seminar inovasi teknologi pertanian.

Badan Litbang Pertanian. 2011. Daun Gamal (Gliricidia sepium) Obat Scabies Pada Kambing. Sinar Tani. Edisi 30 Maret-5 April 2011 No.3399 Tahun XLI.

Becker, K. 2010. Apicomplexan Parasites: Molecular Approaches toward Targeting Drug Development. Germany: WileyBlackwell, pp: 3-20.

Demite, P.R., Feres, R.J., Lofego, A.C. 2015. Influence of agricultural environment on the plant mite community in forest fragments. Braz. J. Biol. 75(2), 396-404.

Ermawati, D. 2011. Untung Menggiurkan Dari Budidaya Kelinci. Penerbit Andi, Yogyakarta.

Jarmuda, S., O'Reilly, N., Zaba, R., Jakubowicz, O., Szkaradkiewicz, A., Kavanagh, K. 2012.
Potential role of Demodex mites and bacteria in the induction of rosacea. J. Med. Microbiol., 61(11), 1504-1510.

Joenoes, N.Z. 2010. Ars Prescibendi Resep Yang Rasional 2. Airlangga University Press. Surabaya.

Khan, M.K., Sajid, M.S., Khan, M.N., Iqbal, Z., Iqbal, M.U. 2008. Prevalence, effects of treatment on productivity and cost benefit analysis infive districts of Punjab, Pakistan. Res. Vet. Sci., 87, 70-75.

Laksono, T.T., Gandul, A.Y., Agus, S., Nunuk, D.R.L., Lucia, T.S., Soeharsono. 2018. Prevalensi dan Tingkat Keparahan (Sarcoptes scabiei) pada Kelinci d Desa Sajen Kecamatan Pacet Kabupaten Mojokerto. J. Parasite Sci., 2(1).

Marimuthu, M., Abdullah, F.F.J., Mohammed, K., Adamu, L., Tijjani, A., Abba, Y., Sadiq, M.A., Ting, L.Y., Saharee, A.A., Haron, A.W. 2015. Comparative treatment approach for Sarcoptes and Psoroptes mite infestation in a Boer cross. J. Adv. Vet. Anim. Res., 2(1), 84-88.

Purwaningsih, N.V., Kardiwinata, M.P., Utami, N.W.A. 2015. Daya bunuh ekstrak daun srikaya (A. squamosa L.) terhadap telur dan larva A. aegypti. Indon. J. App. Chem., 3(3), 96-102.

Suroiyah, F.A., Hastutiek, P., Yudhana, A., Sunarso, A., Purnama, M.T.E., Praja, R.N. 2018. Prevalensi Infeksi Toxocara Cati pada Kucing Peliharaan di Kecamatan Banyuwangi. Jurnal Medik Veteriner, 1(3), 99-104.

Wati, F.A. 2010. Pengaruh Air Perasan Kulit Jeruk Manis (Citrus aurantium sub spesies sinensis) terhadap Tingkat Kematian Larva Aedes aegypti Instar Iii In Vitro [Doctoral dissertation] Universitas Sebelas Maret. 